\title{
Analysis of the Operation Mechanism of American Social Security Fund Wang $\operatorname{Han}^{1 *}$, Liu Longzhu ${ }^{1}$ \\ ${ }^{1}$ State Grid Energy Research Institute Co.,Ltd., Beijing, 102209, China \\ "Corresponding author's e-mail: wanghan@sgeri.sgcc.com.cn
}

Keywords: Social Security Fund, Operation Mechanism, American

\begin{abstract}
At present, China's social security fund operation mechanism is still not perfect. There are many problems and loopholes in the operation and operation of social security funds. How to avoid investment risks and conduct social security fund investment through reasonable and appropriate channels for the security of social security funds Operation and preservation of value added are of great significance. Through the introduction and analysis of the operating mechanism of the American social security fund, this paper hopes to provide reference and reference for the operation mechanism of China's social security fund.
\end{abstract}

\section{American social security fund management model}

The management of the US social security base includes federal government social security fund management, state government social security fund management, and private retirement fund management. The specific work of social security is mainly the responsibility of the Social Security Administration. Different departments are only responsible for one special business, and the division of labor is clear. The investment operation of the social security fund is handled by a specialized organization, and some advisory agencies and organizations supervise and guide the operation and management of the fund.

\subsection{US federal government social security fund management model}

The management of the American federal social security fund adopts a combination of unified management and division of labor management, professional management and consultant participation. The specific work of social security is mainly the responsibility of the Social Security Administration. Different departments are only responsible for one special business, and the division of labor is clear. The investment operation of the social security fund is handled by a specialized organization, and some advisory agencies and organizations supervise and guide the operation and management of the fund.

\subsection{State social security fund management model}

State social security fund management agencies include the State Social Security Administration and the state's internal social security fund management agencies. The state's Social Security Administration is responsible for overseeing the state's social security management, coordinating federal and state governments' social security relationships, and providing federal social security services to citizens. The state's internal social security fund management agency is mainly responsible for the fund management of social security and supplementary guarantees established by each state. The US state government has a very large right to manage social security funds. They can determine the payment standards and payment standards of certain insurance items and determine the investment operation mode of some insurance funds. In some cases, the social fund protection management agencies of the states will jointly discuss a certain issue or jointly supervise a certain institution.

\subsection{Private retirement fund management model}

A private retirement fund refers to an employee social insurance program, or a social insurance plan, which is established by each company independently according to relevant laws or jointly established by multiple enterprise resources. Such private pension funds are generally set up voluntarily by 
enterprises, and are operated by private insurance companies or fund companies. It is a kind of job security and incentive.

\subsection{Social security fund supervision model}

The US Old Age and Survivors Insurance Fund, Disability Insurance Fund, and Medicare Fund are regulated by the federal government, and the Unemployment Insurance Fund is jointly regulated by the federal and state governments. The United States has established a special social security fund custody committee to supervise the old and survivor insurance funds and disability insurance funds, and to make recommendations on the overall operation of the fund and related management rules.

The US government has also set up a Social Security Advisory Council to provide strategic and policy advice to the President, Congress, and the Social Security Administration on social security programs. And the establishment of information disclosure system, so that the use of social security funds is placed under a public supervision environment.

\section{American social security fund Raising}

\subsection{American pension fund raising method}

American pension insurance adopts a fund-raising model of foundation. On the one hand, it focuses on the accumulation of funds to cope with the pension payment of a generation born in the "baby boom" period. On the other hand, it continuously raises the tax rate of social security tax to ensure social security. The operation and issuance of funds.

The American federal social security fundis funded by the State Administration of Taxation to collect social security taxes from employers and employees in a uniform manner throughout the country or to impose special income taxes on self-employed persons. The tax rate depends on the coverage of US social insurance and the extent of beneficiary income. Employers and employees or self-employed persons in the United States each bear half of the payment responsibility according to a certain proportion of their wage income, and the government does not provide subsidies. The tax rate of the endowment insurance tax is adjusted according to the principle of self-care, balance of payments, and a slight balance. The Social Security Administration proposes a plan and submits it to the National Assembly for approval.

\subsection{American medicare fund raising}

The American medical insurance fund mainly comes from the government, enterprises and individuals. The American medical insurance is divided into two parts: "hospital insurance" and "supplemental medical insurance". Hospitalization insurance mainly relies on the collection of medical insurance tax to raise funds, and employees and employers pay a certain percentage of their wages. The payment base for medical insurance is the total income of the employee, and the medical insurance tax paid is deposited in the health insurance trust fund. The supplementary medical insurance fund is mainly derived from the general financial income and the monthly premium paid by the resource insured.

\subsection{Agency of American social security fund management}

The American federal social security fund is mainly responsible for the Internal Revenue Service, the Ministry of Finance, and the Office of the President's Budget and Management. The accounts of the American federal social security funds are directly opened in the Ministry of Finance, and the Ministry of Finance transfers to the management. The collected social security funds are also deposited in the fund accounts without entering the general fiscal accounts.

\section{Investment operations of American social security fund}

Although the United States is a highly developed and open country, the US government is very cautious about the investment and operation of social security funds and pursues a very conservative 
policy. The law has strict restrictions on the way social security funds are invested. Social security funds can generally only add value by purchasing special government bonds.

The US Social Security Act clearly stipulates that the balance of the pension insurance fund can only be used to purchase special bonds issued by the federal government, and must not be invested in any other way, which is legally guaranteed that the federal social security fund may not be used to purchase stocks, or to invest in other areas such as entrusted investment and real estate development. In order to avoid market confusion caused by the large amount of social insurance trust funds buying or selling government bonds on the open market, the US government stipulates that special government bonds purchased by trust funds cannot be listed for circulation. This special national debt has the characteristics of stable yield, flexible term organization, non-listed circulation and less impact on the capital market.

It is not allowed to be listed or transferred, but can only be redeemed, which is very suitable for social security funds.

The United States also uses a portion of social security funds for indexed investments. Index funds are favored by investors because of their low management cost, low system risk and high asset turnover. Therefore, indexed investment has also become an important way for the US social security fund to invest.

In addition, the US government has introduced a "frugal savings plan" for personal account management. The government selects some qualified fund managers to establish and manage the corresponding index funds according to the index selected by the government to track the domestic and foreign stock markets, as a supplementary investment fund for pension funds. Employees allocate funds in their personal accounts to these index funds according to their own wishes, and choose investment strategies with different risk levels.

\section{Characteristics and experience of investment and operation of American social security fund}

At present, the US social security fund's surplus is increasing, and the US aging process is also accelerating, so the US social security fund bears a lot of social responsibility. In order to avoid unnecessary losses caused by investment, it is a safe and reliable choice to choose government bonds with high reputation, strong security, low risk and interest rates higher than the bank deposit interest rate for the same period.

Such investment methods are obviously not conducive to the preservation and appreciation of social security funds. The sustainability of US pension funds is mainly maintained by the rising social insurance tax rate. There has been a lot of debate in the political and academic circles in the United States about this single type of fund investment, and some people have proposed to invest the federal social security fund in the stock market, but they have all been opposed by previous presidents and Congress.

They generally believe that the entry of the federal social security fund into the capital market is a shackle of free market beliefs and a sway to the free market system. They believe that once the government allows social security trust funds to enter the stock market, a large number of social security trusts will have a huge impact on the stock market, and the US government, which can control huge amounts of money, can control or wisdom the equity of any US company directly. Influence the private.

In addition, the entry of the federal social security fund into the market will lead to misplaced resources and crony capitalism, forming a situation of collusion between government and business. In order to protect the interests of the insured and the normal operation of the social insurance fund, they must guarantee the value-added and benefits of the social security fund, thus inevitably causing some unfairness in the capital market. Even some politicians and agents use social security funds for private gains in order to achieve certain narrow political goals. 


\section{Conclusion}

Through the above description, we can find that all aspects of the operation of the US Social Security Fund have a relatively complete legal system to provide support and protection. However, there is currently no special law in China for the supervision and management of the operation of social security funds, which makes the operation of social security funds unacceptable, resulting in moral hazard and fund losses.

\section{References}

[1] Li, B and Zhu, G, Social Security Fund Investment and Advice. Northern Economy, vol. 2, pp. 44-46, 2019.

[2] Jing, $P$ and Chen, M, Difficulties and Strategies of Market-oriented Investment Operation of Pension Insurance Funds. Finance and Economy, vol. 10, pp.76-80, 2017.

[3] Zhu, D, Research on Risk Prevention and Control System of Social Security Fund. Accounting Learning, vol. 26, pp.192+194, 2018.

[4] Zhang, C, Discussion on Strengthening the Management of Investment and Operation of Social Security Funds. Economic and Trade Practice, vol. 3, pp.95, 2018.

[5] $\mathrm{Hu}, \mathrm{X}$, Thoughts on Strengthening the Supervision and Management of Social Security Funds. Guangdong Sericulture, vol. 52, pp.146, 2018. 